UDC 811.111(091)

$811.111^{\prime} 27$

81:32

\author{
Junichi Toyota* \\ Lund University \\ Centre for Languages and Literature \\ Linguistics/Centre for Cognitive Semiotics \\ Lund, Sweden
}

\title{
RICHARD II: HIS HIDDEN LEGACY IN THE ENGLISH LANGUAGE
}

\begin{abstract}
This article examines the possible impact of political policies on the historical changes in the English language during the reign of Richard II. It is argued that his policy to incorporate the French culture into the English court system has had very long-lasting effects on the linguistic activities in the British Isle. He has been considered a villain due to various Tudor propagandas, and his legacy to the English language has been overlooked. A fresh look at various historical events from a politics-free perspective allows us to clearly observe a link between Richard II and various sociolinguistic practices of modern English.
\end{abstract}

Key words: Richard II, language contact, language change, pragmatics, sociolinguistics

\section{Introduction}

The historical development of languages is often considered a gradual process, taking several millennia to complete a certain cycle of change. Since such changes are so gradual, we can see overlapping structures or functions. However, recent research on language contact suggests

\footnotetext{
E-mail address for correspondence: junichi.toyota@englund.lu.se
} 
that language contacts in the past could be the major driving force for historical changes in languages, and contact-induced changes can happen only after several generations (Heine and Kuteva 2005, 2006). On top of this, it is possible to argue that specific people can affect or manipulate language change, whether purposefully or spontaneously. In this paper, we analyse the latter case concerning English, i.e. a person who has unwittingly contributed to the formation of Present-day English (PDE). ${ }^{1}$ This is Richard II. His status has not been given much attention in English historical linguistics, but his political policies have had significant impact on the later development of the English language.

This paper is organised as follows: first, several people highly influential to the development of the English language are highlighted. These people are normally acknowledged as contributing to the establishment of the English language as a national language in England. Along a similar line of argument, Richard II is discussed next. He introduced several new social systems in England, and an attempt is made to clarify the connection between him and these changes in England. After these backgrounds, several specific structures are analysed, including a change of the second person pronoun, the oddity of verbal conjugation and the historical development of the passive voice. These structures are closely connected to the social influence of Richard II.

\section{Important figures in the history of English}

English is known to have been shaped by various factors apart from its internal historical changes, to the extent that OE speakers even copied pronouns from Old Norse (Curzan 2003: 133). The contact with Old Norse is perhaps one of the most significant changes, if not the most. The contact with Norman French is also influential, especially in terms of the expansion of vocabulary. Latin set the standard in the written form in earlier English, mainly due to the fact that Latin was the language of religion and learning (Townend 2006). These contacts were made by groups of speakers of different languages and no one was volitionally acting to influence the

\footnotetext{
${ }_{1}$ The following abbreviations are used: DAT = dative; eModE = Early Modern English; lModE = Late Modern English; ME = Middle English; NOM = nominative; $\mathrm{OE}=$ Old English; PDE = Present-Day English; PL = plural; PRS = present; PST = past; SG = singular.
} 
shape of English at that time. However, there were some specific individuals who contributed to the formation of PDE.

Let us start with King Alfred (reigning 871-899). He promoted the vernacular English and encouraged translation from Latin into English. Written materials prior to his reign that survive to this day are mainly in Latin religious materials such as psalters and gospels. Some poems such as parts of The Dream of the Road (inscribed in runes) or Cædmon's Hymn are found prior to King Alfred, but we find a number of texts written in English after his reign (Blake 1996: 19; Leith 1997: 24). The use of vernacular language was powerful and many felt its influence. From the reign of Henry IV, for instance, the Church prosecuted those who criticised the Church in English, including Chaucer (cf. Section 3.5). So King Alfred's action was a corner stone in the development of English.

In the fifteenth century, the English government employed standardised English for documentation, now commonly known as Chancery English, and scribes were taught and trained to use this standard regardless of their original dialects. Standardisation might have begun but there was no guarantee of its sustenance. The Lancastrian monarch Henry V (reigning 1413-1422), was in favour of standardisation and promoted the use of English in public and official gatherings. In addition, he also ordered the official documentation to be kept in English, not in French. This was perhaps in part due to the fact that he went to war against France (in 1415 and 1417) and his campaigns were successful. This might have created English nationalism and anti-French sentiment. For whatever reason, after the reign of Henry V, the status of the French language in England drastically diminished (Corrie 2006: 111-118).

It is obvious that the above-mentioned contacts and individuals have influenced the shape and the fate of English, but it is still possible to name another individual, Richard II, as a person who contributed to shaping the base of the PDE grammar as it is. King Alfred and Henry V are often mentioned in monographs dealing with the history of English, but Richard II is hardly ever mentioned. Below, we explore how he contributed to the English language. 


\section{Little known legacy: Richard II}

Richard II reigned in England between 1376-1399. For various reasons, he has received negative publicity in English history. Adjectives used to describe him include vain, megalomaniacal, narcissistic, treacherous, vindictive, tyrannical, mad and insane, among others (Jones and Ereira 2005: 203). He indeed commissioned a lifelike portrait for the first time as a monarch in England, but does this make him megalomaniac or vain? Perhaps this can be reinterpreted from different perspectives. He "saw the basis of his power not in overwhelming military force or political intrigue, but in the special authority of sovereignty. His court was a fount not of military authority but of magical power, in which the majesty of royal justice was tempered by the mercy of queenly intercession; it was a court of manners and of ceremony" (Jones and Ereira 2005: 208), filled with the arts, poetry, music, fashion and haute cuisine. This attitude may appear to be normal in the modern world, but his behaviour at the time of his reign may not have been conventional and have frustrated a number of the nobles. He tried to put an end to the Hundred Years' War against France and preferred peace. If knights cannot go to war, they cannot earn much and increase their reputation and power. Thus, they felt that Richard II had deprived them of the chance to thrive as knights.

In this context, it may be easier to understand a common depiction of him as a mad man or megalomaniac, since his rule was against the interests of most of the nobles of that time. Consider, for instance, an earlier belief suggesting that Richard II threw a tantrum, tossing his cape and shoes out of the window, and began to act like a madman upon hearing of the rejection of his order by the king's councillors to put John of Gaunt, the Duke of Lancaster to death. This was repeatedly cited by historians as proof positive of Richard's incipient madness. However, in 1953, "a scholar pointed out that the Victorian editor of the particular chronicle had misplaced the sentence about the cape and shoes, and that it was actually a friar who had pretended to be mad on realizing that his false accusations were about to be exposed" (Jones and Ereira 2005: 204). Was this a mere slip of the pen, or was it done on purpose?

History can be considered as a series of propaganda events, and people can be branded as villains or scapegoats for political purposes. Given the constant power struggle throughout medieval English history, it is possible that Richard II became a target in order to keep a balance in 
this power struggle and appease those who were in power at a particular time. Not surprisingly, he has been victimised, perhaps due to the feud with his successor, Henry IV. Unlike Richard II, who was from the House of Plantagenet, Henry IV and his successor Henry V were from the House of Lancaster. It is highly likely that Richard II was considered the greatest enemy of the Lancaster branch of the family. As soon as Henry IV took over the throne, he manipulated all the historical records in English, such as chronicles kept in abbeys and major churches. "The erasures and revisions still visible in these manuscripts, the removal of criticism of Bolingbroke and his father, and the addition of anti-Richard material show that monks understood perfectly well what that meant" (Jones and Ereira 2005: 207). This trend, interestingly, can be still found later in Tudor England. In Shakespeare's play Richard II, for example, Richard is depicted as an authoritarian figure concerned only with the nobles, making a sharp contrast with his counterpart, Bolingbroke (i.e. Henry IV), who is willing to communicate with different classes of people.

Due to this historical trend, Richard II's achievement is often not given in a positive light. This is perhaps also true in the history of the language. As demonstrated below, the onset of changes can be traced back to the period when Richard II ruled England and thus set new standards in society. Negative publicity throughout the history of England may affect his status and this general false-belief might have kept him out of the frame of the history of the English language. We examine some cases below.

\subsection{European court system in England and addressing the noble}

In the English aristocracy, French culture and language were the norm after the Norman Conquest until the early fifteenth century. This indicates that there was close contact with the continental cultures in England. However, it was not until the reign of Richard II that several rules or practices that we can still find to this day were introduced, including: Addressing a king or queen with titles such as Your Highness, Your Majesty, etc. instead of the former Sire; Everyone was required to bow to the knee to the king or queen. These new practices can be interpreted as vain, and along with propaganda by Henry IV, they earned him names like megalomania. There was a social hierarchy in England before Richard II, but this new standard in English society made it more rigid or clearly visible creating a special 
status for the King and Queen. Having mentioned this, it is important to note that he was merely following a standard from continental Europe and there was no selfishness or megalomania about his behaviour. "In adopting higher terms of address, such as 'Your Majesty' and introducing courtesies such as bowing, Richard was doing no more than importing the fashions that had been current in the courts of Europe for most of the [fourteenth] century" (Jones and Ereira, 2005: 205). Copying different cultures is observed in different parts of the world and this is perhaps one of the factors that influence language change, too (cf. Heine and Kuteva 2005, 2006).

The terms of address, such as Your Majesty, Your Highness, Your Grace, were introduced to England in the early fourteenth century. The examples (1) to (3) are taken from the OED illustrating the first instances listed for each phrase. However, this does not indicate the frequent use of such terms in historical records, and their frequency increased after around 1500. They were all used rather interchangeably earlier, but Your Majesty, originally a translation from French Votre majésté, was acknowledged as an official term by Henry VIII. However, "it was not until the 17th cent. that Your Majesty entirely superseded the other customary forms of address to the sovereign in English. Henry VIII and Queen Elizabeth I were often addressed as 'Your Grace' and 'Your Highness', and the latter alternates with 'Your Majesty' in the dedication of the Bible of 1611 to James I" (s.v. OED majesty n.2.).

Your Majesty (s.v. OED majesty n.2.)

(1) Whanne Alisaundre..wente toward his owne contray, pe messangers..of Affrica, of Spayne, and of Italy come in to Babilon to silde hem to his lordschipe and mageste. (a1387 J. TREVISA tr. R. Higden Polychron. (St. John's Cambr.) IV. 9)

Your Highness (s.v. OED highness n.2.b.)

(2) More can I not write to yowr hynesse at this tyme. (1402 PRINCE OF WALES Let. to Hen. IV (Nat. MSS. I. No. 36))

Your Grace (s.v. OED grace 16.a.)

(3) To his lord he went a pase, And broght him tithinges from hir goode grace. (c1430 Syr Gener. (Roxb.) 1870) 
Judging from these data, perhaps monarchs such as Henry VIII or Queen Elizabeth I may seem to be more responsible for the increase in frequency for these terms, but its onset can be attributed to Richard II. If these terms and the practice of addressing the king had been imported immediately after the Norman Conquest, one would expect the emergence of such terms in English much earlier. This suggests that the social practice of addressing people of a higher social status was a result of Richard II's introduction of the European court system where such terms as Votre majesté were frequently used. This introduction may be a matter of specific terms and a specific social practice, but it has significant subsequent consequences in the English language.

\subsection{You as singular and plural pronoun}

After the introduction of the specific terms discussed in the previous section, a social hierarchy became clearer. This raised awareness of politeness as a volitional action among people. Politeness is often achieved by so-called distancing, i.e. creating a social distance by grammatical coding, including the avoidance of direct mention of an addressee (Hill et al. 1986). There are various tactics for creating politeness, and what is commonly known in British English is a round-about expression for request. This is done in order to achieve distancing to avoid a direct request. Once there is a strict hierarchy in society, distancing becomes a very important social skill. When it is firmly established, it is rather easy to follow a common pattern, but this type of social practice is rather difficult to establish in the first instance.

In addition, the sixteenth century saw a use of yes and yea different from the PDE counterparts in relation to politeness or courtesy (Pope 1972: 195-6, cited in Kitagawa 1980: 115). The use of yes and yea earlier was based on so-called agreement-disagreement type of answering, where saying 'yes' suggests that a speaker in principle agrees with an interlocutor's underlying statement. For instance, for a negative question such as Have you not been to the city centre?, a reply with 'yes' can be followed by I have not. This system is very odd in PDE, but in the agreement-disagreement system, an underlying statement here is 'you have not been to the city centre,' and a speaker merely agrees with this statement, e.g. 'Yes, I agree with the statement, I have not been to the city centre.' In case of eModE, the use of yes was extended to show a sign of attentiveness, i.e. yes was 
used as a sign of marking solidarity with interlocutors, in a sense of 'I am listening.' This is not necessarily politeness, but at least courtesy to others. The common answering system in Indo-European languages is a so-called positive-negative type, and this type is only concerned with the positive or negative aspect of answers. This was a common pattern in English, but only from around the sixteenth century was there a surge of the agreementdisagreement type in England, and this suggests that there was a demand for people to show courtesy to others overtly even in conversation.

Perhaps for this reason, people were rather uneasy and reacted to this standard rather radically and became really cautious about not being rude to others. The use of terms such as Your Majesty is an honorific action, since this is a social norm, but this raises the sense of politeness in English society beyond addressing the nobles, since not to be rude is a selfconscious, volitional action. Old English had a distinction in the second pronoun, between thou (casual/familiar) and ye (formal), as in many continental European languages. It is normally the case that the plural form is more polite than the singular form, and if there is an inclusiveexclusive distinction in pronouns, the first person plural inclusive 'we (inclusive)' is the most polite address (Brown and Levinson, 1987: 203), although English did not have this.

Judging from the chronology of the terms in (1) to (3), the reign of Richard II seems to have made the difference between thou and ye more obvious by introducing the European court system, and people became wary not to be rude. This created an environment where people were oversensitive concerning politeness and when in doubt, they chose to use the polite form ye (Toyota 2005: $336 \mathrm{fn}$. 5). This resulted in the overuse of ye, consequently contributing to the loss of thou from English, although some dialects still maintain this distinction, e.g. H'art tha doing? [how art thou doing] 'How are you doing?' in Yorkshire (Upton 2006: 326).

The avoidance of thou grew to the extent that the singular pronoun was used as a sign of contempt. This pronoun often "co-occurred with terms of abuse, threats, and other negative associations" such as lying (Nevalainen 2006: 195). In addition, it could be even used as a verb, e.g. "to use the pronoun 'thou' to a person: familiarly, to an inferior, in contempt or insult, or as done (formerly universally, now less frequently) on principle by Quakers" (s.v. OED thou v). Some examples are shown in (4) to (6). Notice that in (6), a formal pronoun you is also used as a verb, as a sign of expressing politeness. 
(4) None of hyghenesse schal thou another in spekynge. (c1450 in Aungier Syon (1840) 297)

(5) Avaunt, caitiff, dost thou thou me! I am come of good kin I tell thee! (c1530 Hickscorner (1905) 149)

(6) He thous not God, but you[s] hym. (1564-78 W. BULLEN Dial. agst. Pest. (1888) 5)

As mentioned earlier, politeness can be achieved by means of certain distancing activities, and this can be also understood in relation to the social level. When interlocutors are at the same social level, their social distance is not wide, but communication between two from different social levels can force an increased social distance. In the change of the second person in English, it can be argued that speakers were manipulating this social distance by creating different levels. In creating respect, a speaker can make the status of an interlocutor higher than his own (cf. Figure 1a), but a speaker can also lower his own status to show humbleness. When addressing the nobles, one was forced to be both respectful and humble, creating a maximum social distance (cf. Figure $1 \mathrm{~b}$ ). These relationships can be schematically shown in Figure 1. What is noticeable is that the dotted line is a normal distance between two interlocutors, and after being either respectful (raising the status of interlocutors) or humble (lowering the speaker's status), more distance between interlocutors is created. The use of thou as a sign of contempt is a variation of distancing, although in this case the operation deals with the lowering of interlocutors, as represented in Figure 2, making a sharp contrast with Figure 1a for respect.

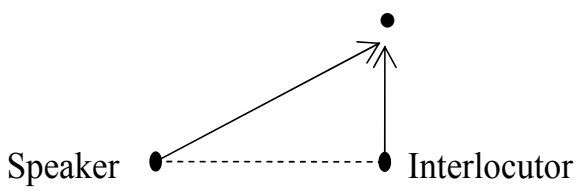

a. Respect

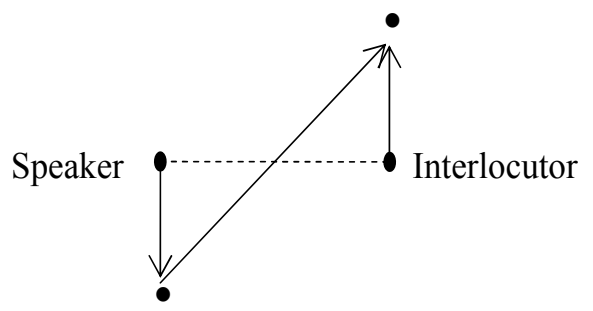

b. Humbleness and respect

Figure 1. Schematic representation of politeness (based od Toyota 2005: 322-323) 


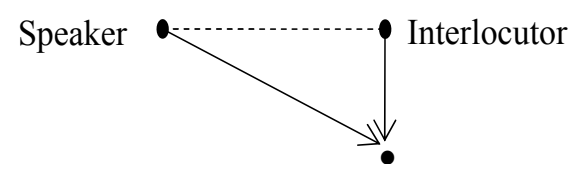

Thou of contempt

Figure 2. Schematic representation for thou of contempt

What the new rule set by Richard II did was to introduce the pattern shown in Figure 1b. This makes common people aware of social differences, but they must have been somewhat reluctant to lower themselves much. However, even with the refusal to lower themselves, thus omitting the lower part of Figure 1b, common people could still raise the status of the hearer. This led to the use of ye as a standard after ME, and its total opposite, i.e. Figure 2, is easily achievable by turning thou into a sign of contempt.

The single second person pronoun you for both singular and plural use stems from various issues concerning politeness. This change bears various consequences in the later development of English. Thus, the legacy of Richard II does not stop here, but also spreads to different parts of the grammar.

\subsection{Oddity of 3SG -s in PDE}

The use of the second person plural pronoun is not the only effect derived from Richard II, and it has yet another effect on the grammatical structure, i.e. verbal conjugation. It has not been much noted, perhaps because it is not obvious when English is analysed on its own. However, in comparison with other languages, the verbal conjugation in PDE is very peculiar, as described below. This is simply an historical accident, but it is a result of social change induced by Richard II. Let us first analyse why the conjugation in PDE is peculiar from historical perspectives.

Old English (OE) has a more complex conjugation than that in PDE, but even at the stage of OE, the verbal conjugation was somewhat simplified. Consider cases of strong and weak verbs in Table 1 . What was unique was the simplified conjugation for the plural form. Unlike the singular form where each person has its specific ending, the plural form does not differentiate persons. Slight differences in the singular forms for strong 
verbs are dialectal, but nevertheless different forms for each person are maintained. This type of conjugation is totally lost in PDE, and as a result, it appears to be simplified. As shown in Table 2, the only marking of a verb is on the third person singular, where a suffix -s is added.

Table 1. OE verbal conjugation

\begin{tabular}{llll}
\hline & & Strong & Weak \\
\cline { 3 - 3 } INF & & bindan 'bind' & hīeran 'hear' \\
PRS & 1SG & binde & hīere \\
& 2SG & bindest/bintst & hīerst \\
& 3SG & bindeð/bint & hīerð \\
& PL & bindað & hīerað \\
\hline
\end{tabular}

Table 2. PDE verbal conjugation

\begin{tabular}{lll}
\hline & SG & PL \\
\hline $1^{\text {st }}$ & bind & bind \\
$2^{\text {nd }}$ & bind & bind \\
$3^{\text {rd }}$ & binds & bind \\
\hline
\end{tabular}

In verbal conjugation, it is important that each language distinguishes between first and second person in order to clarify who is speaking to whom (cf. Croft 2001: 315). Thus, they normally carry some overt markings (such as specific endings). The third person, on the other hand, can be unmarked, since its identity can be unknown to interlocutors and can remain unspecified. As for the number, the plural form (as well as other numbers such as dual, paucal, etc.), not the singular, has a marker for the number unless both singular and plural forms are equally marked (as in, e.g. Latvian). ${ }^{2}$ The combination of person and number yields the third person singular the least marked in the conjugation, as schematically represented in Table 3 (cf. Toyota 2005: 332; Comrie 1977: 11; Silverstein 1985: 243). Thus, the third person singular form often behaves as a stem

\footnotetext{
${ }^{2}$ Note that Modern Breton seems to have developed a system by which older plural-cumsingular nouns can be singularised now by adding a singular suffix, indicating that the plural form can be a base for a singular form. There are, however, only a handful of nouns that behave like this and such cases are clearly marked even within the lexical category noun.
} 
for conjugation or as a base for infinitive, as in the case of Macedonian, since it is the least marked for both person and number.

Table 3. Markedness patterns in terms of person and number

\begin{tabular}{llll}
\hline & SG & PL & \\
\hline $1^{\text {st }}$ & $*$ & $*$ & $\sqrt{ }$ \\
$2^{\text {nd }}$ & $*$ & $*$ & $\sqrt{ }$ \\
$3^{\text {rd }}$ & & & $\sqrt{ }$ \\
\hline
\end{tabular}

Notes: * $=$ markedness for person; $\sqrt{ }=$ markedness for number

In the case of OE, the third person singular is also marked (cf. Table 1), but the first and second persons were at least distinguished earlier in English. The conjugation became simplified in English through history, perhaps due to the contacts with Old Norse earlier and with other dialects later (Nevalainen 2006: 184-185, 196-197). What makes PDE a peculiar language in terms of conjugation is that only the third person singular present indicative form has a suffix -s, i.e. binds from bind. This is supposed to be the least marked combination of person and number, but instead this is the only combination marked for person and number in PDE, as shown in Table 2. This conjugational pattern is extremely rare in the world and no language operates like PDE. ${ }^{3}$ When attention is paid to different dialects in PDE, some have no marking for any person and number (East Anglia, e.g. He do his work) or the $-s$ marking for every person and number (West Yorkshire I does my work or We does our work). Their systems, although non-standard and often stigmatised, are more logical or conform to a typologically common pattern. How did the typologically unnatural pattern happen in PDE, then?

The loss of thou as the second person singular pronoun triggered the loss of the marking for the second person, e.g. thou normally carried the -st ending as in thou tellest, thou may'st, thou dost, etc. Along with the earlier third person singular ending (i.e. $-s$ or -th), singular persons were all clearly distinguished as shown in Table 1 . The lack of thou, along with the assimilation of the plural form into the first person singular form, made the conjugation somewhat crippled, leaving the third person singular the

\footnotetext{
3 Note, however, that some Papuan languages, such as Fasu or Hua, can behave against the common pattern shown in Table 3, although not like PDE.
} 
only marked form in PDE. This change would not have happened without the loss of thou. Otherwise, the second and third person singular form would have retained some markings. Thus, it is possible to claim that the peculiarity in the conjugational pattern in PDE was initially influenced by the awareness of politeness and the loss of the second person singular pronoun thou. This trend was set by Richard II and therefore, the oddity of conjugation in PDE was indirectly created by him.

\subsection{Passive and politeness}

As observed in the change of pronouns, people in England became increasingly aware of politeness after the reign of Richard II. This may have had an impact on another grammatical structure, i.e. the passive voice. The passive voice allows speakers to refer to events without mentioning a doer, which allows them to achieve various social and pragmatic functions, such as avoiding responsibility, keeping the identity of the agent ambiguous, as well as keeping a distance from events and implying objectivity in statements. What is prominent among them is commonly known as impersonalisation and this is often considered as the main function of the passive voice (cf. Keenan 1975; Comrie 1977; Shibatani 1985; Brown and Levinson 1987: 273-275). This can be considered as one of the grammatical features indirectly influenced by Richard II's reign.

In the history of English, impersonalisation could previously be achieved by several different tactics, and the most common one in $\mathrm{OE}$ was the use of indefinite pronouns or generic nouns such as man. They are collectively called indefinite pronouns here. Six different ones have been used for impersonalisation throughout the history of English: man (until the $15^{\text {th }} \mathrm{C}$ ), thou 'you (SG)' (until the $16^{\text {th }} \mathrm{C}$ ), we (from the mid $10^{\text {th }}$ $\mathrm{C}$ ), one (from the $13^{\text {th }} \mathrm{C}$ ), they (from the $14^{\text {th }} \mathrm{C}$ ), you (from the $16^{\text {th }} \mathrm{C}$ ). Figure 3 summarises the chronology of these indefinite pronouns. Man was perhaps the most common pronoun for impersonalisation among them, as demonstrated in (7) and (8) until it gained a new sense, 'male person' (Mustanoja 1960: 222). This shift happened around the late ME period. However, what was characteristic in earlier English was that many personal pronouns, although referential in nature, were often used as indefinite pronouns on purpose. One such case is illustrated in (10), where we can be referential, but used as an indefinite pronoun for impersonalisation. 
Similar to this case, the pronoun you we saw earlier was chosen on purpose not to be rude and is closely related to impersonalisation, i.e. the plural form is easier for achieving impersonalisation than the singular form, and it can be used as an indefinite pronoun, as shown in (10).

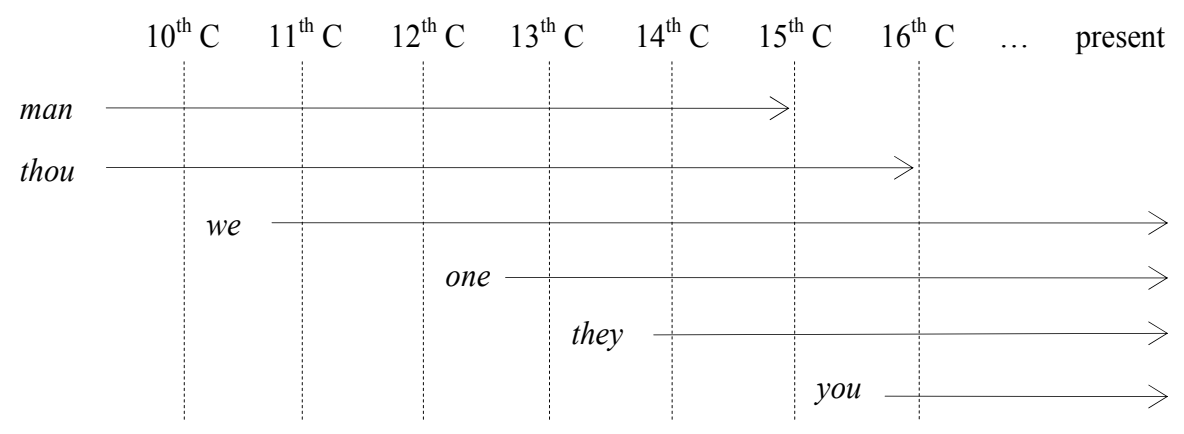

Figure 3. Diachronic change of indefinite pronoun or generic noun in English (Toyota 2005: 329).

(7) pætmon his winedryhten wordum herge. thatone.NOM his lord.and.friend word.DAT.PL honour.3SG.PRS 'that one honours his lord and friend in words' (Beowulf 3176)

(8) Man brohte pa his heafod on anum disce. onebring.PST then his head in alone dish 'And his head was brought in a charger.' (West Saxon Gospels: Matt. (Corpus Cambr.) xiv. 11)

(9) Beowulf mapelode ...: We pæt ellenweor ... feohtan fremedon

Beowulf spoke we that valorous.deed with.battle performed 'Beowulf said: valorous deed was performed in the battle.' (Beowulf 958)

(10) You shall sometime have one branch more gallant than his fellowes. (1577 GOOGE Heresbach's Hush. 11. (1586) 87) 
Speakers may want to hide the identity of others, for various reasons. It is possible that the identity is not known and impersonalisation has to be employed. However, it can be a sign of politeness if it is done purposefully. In real-life situations, it is common to see impersonalisation in gradience, and it is often up to hearers to measure the degree of politeness with this gradience (Watts 2003: 68). In addition, impersonalisation can be more closely associated with politeness in a culture where politeness plays an important role in social interaction, e.g. Asian countries (cf. Brown and Levinson 1987). As already seen in Section 3.2, there was a change in the social practice in England and impersonalisation can be an important linguistic tactic in verbal communication.

Generally speaking, this type of volitional choice to be polite or rude was common in earlier English, but not in PDE, and a number of earlier choices are now grammaticalised as a social norm, i.e. politeness has turned into honorific. The address to the noble, for instance, was a social norm set by Richard II, and this was one of the first changes in this domain of social interaction. As the English language developed, speakers faced the lack of manipulatable constructions for politeness, but politeness still played a major role in the society. This was perhaps the social force for speakers to search for a new structure.

The passive voice is known to be used for impersonalisation, but the history of the passive voice in English is reasonably recent, and it was fully grammaticalised around late Middle English or early Modern English, i.e. it is only ca. 400 to 500 years ago, although the onset of changes can be detected even in Old English. The earlier passive was a perfective aspectual construction. This aspectual structure was defective, since only the undergoer (patient) was allowed as the overt grammatical subject. Thus, examples like (11) from OE are not necessarily instances of the passive voice. In addition, these examples often translate as a perfective aspect in PDE, and thus, the translation in (11) is 'had brought', not a simple past tense 'brought'. Ambiguous cases like this are persistent; some even claim that examples can be found even in the nineteenth century (Rydén and Brorström 1987: 24). In addition to this aspectual change and actor-undergoer orientation, there is another important change in the copula. The earlier passive-like sentence was stative, since its aspectual reading is derived from the copula verb, which is inherently stative. In other words, the aspectual representation of the whole sentence depended on the copula be. However, this has changed and after the late ME period, 
the whole clause became predominantly dynamic, which indicates that the aspect at the clause level represents the one from the past participle, i.e. there was a semantic bleaching on the part of the copula, and it has lost its verbal nature and has become an auxiliary (Toyota 2008: 5159). After all these changes, the entire clause can be considered to have been grammaticalised. In statistical analysis, it has been claimed that the aspectual shift was more or less completed around the late ME/eModE period, as demonstrated in Table $4 .{ }^{4}$

(11) Old English

Đa him ða ठæt sæd broth wæs,...

when him then the seed brought was

'When someone had brought him the seed, ...' (Bede 4 29.366.30)

(11) Late Modern English

Our hopes are again revived of seeing the Viceroy of Mexico. (1797 Nelson, Letters, ed. Naish (1958) 190 p., 328 (30 Jun.))

Table 4. Aspectual change in the English passive (Toyota 2008: 17)

\begin{tabular}{llllll}
\hline & OE & ME & eModE & lModE & PDE \\
\hline Dynamic & 395 & 1033 & 2458 & 7121 & 8632 \\
& $(34.5 \%)$ & $(67.5 \%)$ & $(72.2 \%)$ & $(77.5 \%)$ & $(79.4 \%)$ \\
Stative & 661 & 368 & 701 & 1406 & 1762 \\
& $(57.2 \%)$ & $(24.1 \%)$ & $(20.5 \%)$ & $(15.3 \%)$ & $(16.2 \%)$ \\
Ambiguous & 99 & 128 & 232 & 661 & 478 \\
& $(8.6 \%)$ & $(8.4 \%)$ & $(6.8 \%)$ & $(7.2 \%)$ & $(4.5 \%)$ \\
Total & 1155 & 1529 & 3418 & 9188 & 10872 \\
& $(100 \%)$ & $(100 \%)$ & $(100 \%)$ & $(100 \%)$ & $(100 \%)$ \\
\hline
\end{tabular}

The grammaticalisation of the passive involves various different factors, but its use relating to politeness cannot be overlooked. It has been argued that the decrease of these indefinite pronouns correlates with the emergence of the passive (Toyota 2005). Notice that the PDE translations for (8) and (9) use the passive voice. From the perspective

${ }_{4}$ Corpora used for this statistical result are: Helsinki corpus (for OE, ME and eModE); ARCHER corpus (for 1ModE); London-Lund corpus (for PDE spoken data); Lund-Oslo-Bergen corpus (for PDE written data). 
of PDE, earlier indefinite pronouns are a substitute for the passive, e.g. "the idea [of the passive voice, J.T.] was expressed by the impersonal man 'one' with the active voice" (Mitchell and Robinson 1992: 111; see also Mustanoja 1960: 226-227, 438). The result shown in Figure 3 and Table 4 also suggests that the decrease of the indefinite pronoun man and the increase of frequency of the passive happened around the same period. It may take several centuries for these changes to happen and there are some functional overlaps during this time, but what unites them is most likely impersonalisation. The functional motivation seems very strong in the grammaticalisation of the passive voice.

In conjunction with man, the second person pronoun was no longer an obvious sign of politeness, and impersonalisation could not be easily achieved by pronouns. It is possible to assume that the passive voice would have evolved on its own in the course of natural development. However, due to its structure, which allows speakers not to mention the agent, the use of the passive voice was convenient for the purpose of politeness and it would not have been established so firmly without changes in the indefinite pronouns. This co-relation of different structures reflects the awareness of politeness in earlier English society, and it can be argued that the passive voice would not have been so firmly established without this trend.

\subsection{Gender shift in earlier English}

Apart from the politeness-related issues, it seems possible that Richard II somehow influenced various linguistic issues concerning gender distinction in England. The court of Richard II was a manifestation of refinement and sensitivity. This is when a particular literary tradition in England emerged, e.g. Geoffrey Chaucer. During Richard II's reign, the Church was more open-minded and allowed various activities, including satire and lampoon in the name of arts performed by minstrels to which Chaucer himself belonged. Note that this openness was only possible under Richard II, and once he was murdered and Henry IV took over the throne, the status of the Church was reinstalled as an authority and they started prosecuting people who criticised the church, especially in the vernacular language. This put Chaucer in a difficult position and it is likely that his works were considered heretic by the new Church regime. This shift in politics might have killed one of the greatest English poets (Jones et al. 2003). 
This type of open-mindedness during Richard II's reign also extended to difference in sexes. His court was unique at that time in the sense that women enjoyed a high profile: There was a clear existing social division based on gender, and certain roles were normally associated only with males and others only with females. It was Richard II that tipped this balance, and these gender roles became somehow obscured under his reign. In addition, Richard II was the first king to appoint a duchess, Margaret Marshall in 1397, which is a sign that he acknowledged potential in the female. "Women also took on important roles in government; and Richard II's queen, Anne of Bohemia, was seen as a crucial restraining hand on the implacable justice of the king" (Jones and Ereira 2005: 182).

By the end of the fourteenth century many women were in positions of considerable power, and courtly society in England had become increasingly feminised, quite similar to the court created by Richard II. This was partly aided by the Black Death during the twelfth century; this disease left a catastrophic impact on the British Isle as well as the rest of Europe, wiping out a considerable proportion of the population. By the mid twelfth century, due to the shortage of manual labourers, women were forced to do what had been previously considered male jobs. This 'improved' the social status of women in general, since they were given more responsibility. However, once the country had recovered from the impact of the Black Death, this trend soon met a backlash of male dominance in society, and by the mid fifteenth century the suppression of women's status was in full swing, aided by the Church reemphasising the sin committed by Eve in the Garden of Eden.

These social movements are observable in different aspects of Medieval English society, including the language. One instance illustrating Richard II's influence on the grammar is the meaning shift in the generic personal noun, man. This was originally used to refer to people in general, i.e. "As a designation applied equally to particular individuals of either sex" (s.v. OED man, n. (and int.), 1†a.) and it is sometimes considered even as a pronoun (s.v. OED, †man, pron.). From the Modern English period onwards (cf. Figure 3 ), its semantic referent became restricted to a male person, perhaps due to the intensification of meaning 'a male person' as contrasted with 'a woman' (Meier 1953). This was not the intention of Richard II, but it is possible to claim that the system in his court created a ground where women could be suppressed later, i.e. the status of women after the reign of Richard II would not have been affected much if it had not been elevated so much during 
his reign. Nevertheless, it is true that female referents are more likely to be subjected to pejoration and more terms derogatively referring to them are found after ME (Curzan 2003: 136-158; see also Kleparski 1997 for examples), and this was even more clearly visible towards the Renaissance period to the extent that the grammatical gender was also manipulated as part of socio-political propaganda. For instance, a passage from a seventeenth century grammar book reads "The masculine gender is more worthy than the feminine" (Poole 1646: 21). Some residues can be still seen to this day, e.g. female referents normally carry negative connotation in sex-based pairs such as master v. mistress, bachelor v. spinster.

There seems to be a general pattern of semantic change concerning referents of both males and females. "Words have shifted their primary meaning almost exclusively from 'child' - male or female - to 'servant,' and from there, often to a morally or sexually deprived person" (Curzan 2003: 144). For instance, PDE knight is derived from OE cniht 'a boy, youth, lad' (s.v. OED, knight, n. I.†1.). It went through a stage of 'servant', but its servitude was restricted in a sense of military, i.e. a military servant to people of high rank, including a king. This is a case of male referents and knight normally does not have a negative sense. Female counterparts such as maid, wench, slut, trull, etc. used to mean simply 'girl' without any extra implication, but now they all have a negative connotation of varying degrees. In addition, some social changes also influenced the meaning shifts. OE wif 'woman (of a low degree)', often forming a compound wifmann 'woman', shifted its meaning to 'a domestic servant.' This shift follows a common pattern, but it coincided with the Norman Conquest. This event imposed the feudal system in England, which makes a sharp contrast against AngloSaxon social practice. In Anglo-Saxon times, men and women normally shared more equal rights, but this system was completely abolished, and a married woman in England lived in complete submission to her husband (Fell, Clark and Williams 1984; Norberg 1996: 120-21). Thus, OE wif became 'a servant to her husband', i.e. the origin of 'wife' in PDE. This social change might have contributed to the meaning change and solidified new meanings as found in PDE.

This type of example does not explain the grammatical structure itself, but it reflects on social attitudes towards women after the reign of Richard II. He inadvertently changed social practices concerning women, which triggered a later backlash suppressing their status. There were some socio-historical accidents affecting women's status, but it seems plausible 
to assume that without the changes made by him, the pejoration of female referents may not have been this extreme in English. In this sense, the current gender inequality at the grammatical/lexical level may owe its existence to the reign of Richard II.

\section{Legacy of Richard II}

Some grammatical features in PDE are taken for granted, but they can appear very peculiar once compared with other languages. The case of the third person singular present indicative suffix $-s$ is a good example to illustrate this point. These grammatical features may be a result of naturally occurring spontaneous changes, but features analysed in this paper so far are hardly such cases. One possible reason for change is language contact, and English was indeed influenced largely by contact with Old Norse, concerning the loss of case marking, simplification of verbal conjugation, etc. (Toyota forthcoming). However, a kind of contact that influenced structures we have seen is the contact with the European court system, which was first introduced by Richard II to England. The subsequent social changes brought up by the introduction of this continental culture are responsible for the various grammatical changes observed in this paper. This point has not been noted in linguistic studies.

The legacy of Richard II may not be so visible in PDE, but it is clearly found in historical changes. He was unique in many senses in the fourteenth century, but "Richard has created a new vision of royalty in England, in which the king was a majestic figure in a court that was as concerned with the arts of peace as those of war. The function of majesty was to create a focus of authority that would be as effective in times of peace as of war. Henry IV and each succeeding sovereign would, in fact, attempt to build on what Richard had done" (Jones and Ereira 2005: 208). Due to propaganda, he has been given a negative reputation, but his achievements and political policies are still influential across English society and the language. Without his reign, the structure of PDE would be totally different. 


\section{Summary}

This paper has presented how a single person can influence the development of English even after his death. Richard II set some standards in Medieval English society, and although he has gained negative publicity, the standards he set, such as a court of manners and of ceremony, persisted. For instance, some parts of the English grammar have been taken for granted and have not been studied in detail, and as this work has shown, some aspects of change can be related to the social changes Richard II introduced. The introduction of awareness of politeness indeed created a significant impact on English society, which consequently affected the language.

His legacy on grammar can be seen as a chain-effect, one change effecting the next one. The first change is the change in the second person pronoun, when the polite plural form ye overtook the paradigm of the familiar singular form thou. This change in pronouns (the loss of thou-ye distinction) made conjugation in English typologically very odd, with the third person singular the only marked combination of person and number. Also, due to the increasing awareness of politeness, the change in the indefinite pronouns caused a problem, since they became less indefinite and more referential. This change caused speakers difficulties, which helped the passive voice to be firmly established as a replacement for the earlier indefinite pronouns. Richard II also made some fundamental changes in the status of women during his reign, which had significant consequences in a later gender shift concerning female referents, i.e. females are more prone to pejoration. This was not his intention, of course, but it seems that his court created an atmosphere to breed a backlash against improvement of the status of women.

The passive voice and the change of the second person pronouns have been a common topic for researchers, but the typological oddity in the conjugation of PDE is hardly ever mentioned. All these grammatical features, whether commonly studied or not, have not been connected to the influence made by Richard II. As demonstrated throughout this paper, although little is acknowledged, Richard II is an important figure in the formation of PDE and his legacy should be given more attention in the field of linguistics. 


\section{References}

Blake, N. F. (1996). A History of the English Language. Basingstoke: Palgrave.

Brown, P. and S. Levinson (1987). Politeness: Some Universals in Language Usage. Cambridge: Cambridge University Press.

Comrie, B. (1977). In Defence of Spontaneous Demotion: Impersonal Passive. In: P. Cole and J. M. Sadock (eds.), Syntax and Semantics (Vol. 8): Grammatical Relations, New York: Academic Press, 47-58.

Corrie, M. (2006). MiddleEnglish-Dialects and Diversity. In: L. Mugglestone (ed.), The Oxford History of English, Oxford: Oxford University Press, 86-119.

Croft, W. (2001). Radical Construction Grammar. Oxford: Oxford University Press.

Curzan, A. (2003). Gender Shifts in the History of English. Cambridge: Cambridge University Press.

Fell, C., C. Clark and E. Williams (1984). Women in Anglo-Saxon England and the Impact on 1066. London: British Museum Publications.

Heine, B. and T. Kuteva (2005). Language Contact and Grammatical Change. Cambridge: Cambridge University Press.

Heine, B. and T. Kuteva (2006). The Changing Languages of Europe. Oxford: Oxford University Press.

Hill, B., S. Ide, S. Ikuta, A. Kawasaki and T. Ogino (1986). Universals of Linguistic Politeness. Journal of Pragmatics, 10, 347-371.

Jones, T. and A. Ereira. (2005). Terry Jones' Medieval Lives (paperback edition). London: BBC Books.

Jones, T., R. Yeager, T. Dolan and A. Fletcher (2003). Who Murdered Chaucer: Medieval Mystery. London: Methuen.

Keenan, E. L. (1975). Some Universals of Passive in Relational Grammars. Chicago Linguistic Society, 11, 340-352.

Kitagawa, C. (1980). Saying "Yes" in Japanese. Journal of Pragmatics, 4, 105-120.

Kleparski, G. A. (1997). Theory and Practice of Historical Semantics: The Case of Middle English and Early Modern English Synonyms of GIRL/YOUNG WOMAN. Lublin: University Press of the Catholic University of Lublin.

Leith, D. (1997). A Social History of English. London: Routledge.

Meier, H. H. (1953). Der indefinite Agens im Mittelenglischen 1050-1350: die Wörter und Wendungen für 'man'. Swiss Studies in English XXXIV. 
Mitchell, B. and F. C. Robinson (1992). A Guide to Old English ( $5^{\text {th }}$ ed.). Oxford: Blackwell.

Mustanoja, T. F. (1960). A Middle English Syntax (vol. 1). Helsinki: Société Néophilologique.

Nevalainen, T. (2006). Mapping Changes in Tudor English. In: L. Mugglestone (ed.), The Oxford History of English, Oxford: Oxford University Press, 178-211.

Norberg, C. (1996). Chaucer's Women: Female Occupational Terms in the Canterbury Tales. In: G. Presson and M. Rydén (eds.), Male and Female Terms in English: Proceedings of the Symposium at Umea University, May 18-19, 1994, Uppsala: Swedish Science Press, 115-134.

OED = Oxford English Dictionary (2 ${ }^{\text {nd }}$ ed.) (1989). Oxford: Clarendon Press.

Poole, J. (1646). The English Accidence (reprinted in 1967). Menston (Yorks.): The Scolar Press, Ltd.

Pope, E. N. (1972). Questions and Answers in English. Ph.D. dissertation, MIT.

Rydén, M. and S. Brorström. (1987). The 'Be/Have' Variation with Intransitives in English: With Special Reference to the Late Modern English. Stockholm: Almquist \& Wilksell International.

Shibatani, M. (1985). Passive and Related Constructions: A Prototype Analysis. Language, 61, 821-848.

Silverstein, M. (1985). Language and the Culture of Gender: At the Intersection of Structure, Usage and Ideology. In: E. Mertz and R. J. Parmentier (eds.), Semiotic Mediation: Sociocultural and Psychological Perspectives, Orlando: Academic Press, 219-259.

Toyota, J. (2005). Politeness as a Distancing Device in the Passive and in Indefinite Pronouns. In: J. Skaffari, M. Peikola, R. Carroll, R. Hiltunen and B. Wårvik (eds.), Opening Windows on Texts and Discourses of the Past, Amsterdam: John Benjamins, 319-339.

Toyota, J. (2008). Diachronic Change in the English Passive. Basingstoke: Palgrave, 2008.

Toyota, J. (forthcoming). English Grammar through Time: Typological Perspectives. Cambridge: Cambridge University Press.

Townend, M. (2006). Contacts and Conflicts: Latin, Norse, and French. In: L. Mugglestone (ed.), The Oxford History of English, Oxford: Oxford University Press, 61-85. 
Upton, C. (2006). Modern Regional English in the British Isles. In: L. Mugglestone (ed.), The Oxford History of English, Oxford: Oxford University Press, 305-333.

Watts, R. J. (2003). Politeness. Cambridge: Cambridge University Press.

Received: 8 June, 2011

Accepted for publication: 15 October, 2011

\section{Јунићи Тојота}

\section{РИЧАРД ІІ И ЊЕГОВО СКРИВЕНО НАСЛЕЪЕ У ЕНГЛЕСКОМ ЈЕЗИКУ}

\section{Сажетак}

Чланак разматра могући утицај политичких дешавања на историјску промену енглеског језика за време владавине Ричарда II и заступа мишљење да је његова политика увођења француске културе на енглески двор произвела дуготрајан утицај на језичку активност Британских острва. Захваљујући свакојакој пропаганди коју су спроводили Тјудори, Ричард II сматран је за зликовца, а наслеђе које је оставио енглеском језику је дуго било пренебрегнуто. Један другачији поглед на историјске догађаје тога времена из неполитичке перспективе пружа нам могућност да јасно сагледамо везу између Ричарда II и разнолике социо-језичке праксе у савременом енглеском језику.

Кључне речи: Ричард II, језички контакти, језичка промена, прагматика, социолингвистика 